\title{
Maritornes and genetics
}

\author{
Raúl P. Valdez, M.D. ${ }^{a}$
}

\begin{abstract}
Maritornes is a female character created by Cervantes for Don Quixote. She appears in several chapters of part one and takes on a greater role in chapters XVI and XLIII. In her first appearance in chapter XVI, Cervantes describes Maritornes as having physical signs compatible with a genetic disorder. According to this description, the objective of this article was to pose the possibility that, in 1605, Cervantes described Maritornes as a woman with a genetic disorder.

Key words: Maritornes, genetics, Quixote.
\end{abstract}

http: / / dx.doi.org/10.5546/ aap.2020.eng.61

To cite: Valdez RP. Maritornes and genetics. Arch Argent Pediatr 2020;118(1):61-63.

\section{INTRODUCTION}

Maritornes is a female character created by Cervantes for Don Quixote. She appears in several chapters of part one and takes on a greater role in chapters XVI and XLIII.

Her first appearance, in chapter $\mathrm{XVI}$, is described as follows: "There was besides in the inn, as servant, an Asturian lass with a broad face, flat poll, and snub nose, blind of one eye and not very sound in the other. The elegance of her shape, to be sure, made up for all her defects; she did not measure seven palms from head to foot, and her shoulders, which overweighted her somewhat, made

a. School of

Biomedical Sciences, Universidad Austral, Pilar, province of Buenos Aires, Argentina.

E-mail address:

Raúl P. Valdez, M.D.: rvaldez@austral.edu.ar

Funding:

None.

Conflict of interest:

None.

Received: 12-15-2018 Accepted: 7-22-2019 her contemplate the ground more than she liked."1

Her second appearance takes place across chapters XXXII, XXXV, XLIII, and XLIV, when Don Quixote returns to the inn after paying penance at Sierra Morena.

The objective of this article was to pose the possibility that the character Cervantes described as Maritornes was a young woman with a genetic disorder or syndrome, possibly Down syndrome, due to its frequency, or Noonan or Turner syndrome.

Down syndrome is a genetic condition caused by the presence of a third copy of chromosome 21. For this reason, it is also known as trisomy 21. It is characterized by the presence of a variable degree of cognitive disability and physical traits that make individuals easily recognizable..$^{2-4}$

The eponym comes from John L. Down, an English physician who first described the syndrome in 1866. In 1958, French investigator Jérôme Lejeune discovered that Down syndrome was an alteration in chromosome 21. The incidence of Down syndrome is, in average, $1 / 700$ births, but ranges depending on maternal age and may reach $1 / 30$ births among women aged 45 years.

Noonan syndrome was first described by Jacqueline Anne Noonan in 1962. It is the second most common genetic disorder (incidence of $1 / 1000$ births). Turner syndrome is less common $(1 / 5000)$. It is a female-only disorder with a partial or complete monosomy of the second $X$ chromosome $(45, \mathrm{X} 0){ }^{4}$

\section{Did Maritornes have a genetic disorder?}

Let us go back to the description of Maritornes in chapter XVI, now from a medical perspective, in an attempt to relate her physical signs to the syndromes mentioned above..$^{2-4}$

There was besides in the inn, as servant, an Asturian lass with a broad face (a), flat poll (b), and snub nose (c), blind of one eye and not very sound in the other (d). The elegance of her shape, to be sure, made up for all her defects; she did not measure seven palms from head to foot (e), and her shoulders, which overweighted her somewhat, made her contemplate the ground more than she liked ( $f$ ).

(a) Brachycephaly / flat facial profile or broad face.

(b) Short neck or flat poll.

(c) Low nasal bridge or snub nose. 
(d) Strabismus or blind of one eye and not very sound in the other.

(e) Short stature or did not measure seven palms from head to foot.

(f) Kyphoscoliosis or her shoulders, which overweighted her somewhat, made her contemplate the ground more than she liked.

\section{DISCUSSION}

Based on this description, most likely, Cervantes saw and described a young girl with Down syndrome, as the first option, or with Noonan or Turner syndrome. In 1916, Sánchez Rojas focused on Maritornes' physical description, but did not relate it to Down syndrome, ${ }^{5}$ which was already known back then; likewise, in 2005, García Barreno paid attention only to Maritornes' bad breath and failed to associate any of the physical signs described by Cervantes with a genetic disorder. ${ }^{6}$ The question is about the other signs or symptoms we now know about Down, Noonan or Turner syndrome and why they are not described in Maritornes.

In the case of Down syndrome, trisomy 21 has many clinical manifestations, but not all of them need to be present in the same person simultaneously. Over time, and with scientific advances, more physical traits and signs have been described in addition to those originally observed by Down in 1866. Trisomy 21 provides approximately $1 \%$ of the genetic information to an individual with 400 genes. These 400 genes encode the syndrome's characteristics or manifestations, but they are very extensive and only some are known. So, it is necessary to understand that each person with Down syndrome has a high degree of individuality ${ }^{7}$ and that clinical manifestations vary greatly, with different percentages. In turn, some physical sings are shared by Maritornes and the three possible syndromes mentioned here.

Therefore, the genetic condition and phenotype described by Cervantes in Maritornes may correspond to one of these syndromes with different degrees of variability and may tip the scales in favor of one or the other, but it is not possible to make an accurate diagnosis. Anyway, this is not little and we could not have asked more of a literary text that was first published in 1605. Therefore, I believe it is a valid suspicion and, most likely, Maritornes certainly had Down syndrome as a first option, or rather, that Cervantes was seeing and describing in his work a young woman with the physical traits typical of Down syndrome. To be strict in terms of genetics, it is necessary to also consider the possibility of a different clinical situation: Noonan syndrome, because it involves most of the signs described by Cervantes, ${ }^{8}$ and Turner syndrome, as the second and third options, respectively. We should also ask ourselves about what happens with the clinical characteristics that we now know are present in most individuals with this type of genetic disorders but were not described explicitly by Cervantes in Maritornes. Specifically, I mean cognitive disability.

First, it is necessary to clarify that cognitive disability is not present in every person in the same manner or to the same extent. ${ }^{4}$ First of all, Cervantes described external physical features, and did so actually pretty well. He could have never described a congenital heart malformation in the $17^{\text {th }}$ century. That is why it is believed that Cervantes' depiction of Maritornes' physical appearance is enough to suspect one of the genetic disorders mentioned here. Throughout Don Quixote, Cervantes portrayed many other clinical conditions that have been studied. ${ }^{6}$ The physical description of Maritornes is one of those. Still, it is worth paying attention to her cognitive ability.

Let us refer to two aspects: Maritornes' cognitive ability and sexuality, certainly two close dimensions. Sexual ability and libido are not excluded from genetic conditions. ${ }^{9}$ Hormonal changes in these individuals are the same as in other people. The difference lies in the ability to understand and manage them in a person with certain cognitive disability. ${ }^{9,10}$ Maritornes is sexually active and described by the innkeeper as a homely prostitute. For sure, the failed love affair with the carrier in chapter XVI was not an isolated episode. Cervantes emphasized this: "The carrier had made an arrangement with her for recreation that night, (...) and it is said of this good lass that she never made promises of the kind without fulfilling them."1

Maritornes' libido and cognitive vulnerability result in the perfect combination for carriers to take advantage of her the night they spend at the inn. ${ }^{5,10}$ The carrier was waiting for his "bribe,"1 and the innkeeper confirms his suspicion when calling her out: "Where are you, you whore? All this has to be your doing!" This is repeated so many times that it seems to be something known by the innkeeper. ${ }^{1}$ Besides, Cervantes says that Maritornes "held it no disgrace to be in such an employment as servant in an inn, because, she said, misfortunes and ill-luck had brought her to that 
position."1 Such suspicion is also supported by Sánchez Rojas: "Maritornes soon returned to the primal vexations of the inn," "Maritornes, the homely whore of part one."11

Poor Maritornes is the servant at the inn, kindhearted and helpful, having sexual intercourse with carriers and always keeping her word but without enough resources to lead a different life. She is not a flighty girl and does not consider prostitution as a life choice. This is probably how cognitive disability was seen in 1605. Maritornes does not have a family to protect her nor lies in a society that cares about her. The situation should be analyzed in context, considering that this was a $17^{\text {th }}$ century inn beside the road, not from the scientific, inclusive perspective of the $21^{\text {st }}$ century.

Ultimately, Maritornes has external physical traits that are most likely related to a genetic disorder and also shows some vulnerabilities that lead to the suspected diagnosis. Of course, in his fictional work, Cervantes created a character that may have been inspired by a real person with Down syndrome or other genetic disorder.

It is also worth noting another distinctive feature of Maritornes' personality: her ability to help others in need. Not only she helps to take care of a battered Quixote, she is also a sweet girl capable of being touched by Sancho and offering to "pay herself" ${ }^{1}$ a glass of wine to soothe the blanketed squire.

Maritornes' visible physical traits are mostly consistent with what we now call Down syndrome, Noonan syndrome or Turner syndrome. In addition, it is also suspected that, given her vulnerability, Maritornes had a cognitive disability, but this is not a judgment about her behavior but rather an understanding perspective allowed by four centuries of history.

\section{Acknowledgments:}

Ángeles Valdez, Literature Professor; José Luis Lazzarini, Jesuit priest; Fernando Burgos, Pediatrician; and María Adela Bertella, Psychologist.

\section{REFERENCES}

1. Cervantes M. Don Quijote de la Mancha. Madrid: Real Academia Española-Asociación de Academias dela Lengua Española; 2015.Page 138.

2. Corretger JM, Serés A, Casaldaliga J, Trias K. Síndrome de Down: Aspectos médicos actuales. Barcelona: Masson; 2005.

3. Conn R. Genetics. In Lissauer T, Carroll W. Illustrated Textbook of Paediatrics. $5^{\text {th }}$ ed. London: Elsevier; 2018.Page 122.

4. Bacino CA, Lee B. Citogenética. In Kliegman R, Stanton B, St. Geme J, Schor N. Nelson. Tratado de Pediatría. $20^{\mathrm{a}}$ ed. Elsevier; 2016.Pages 634-56.

5. Sánchez RojasJ. Maritornes. In:Sánchez RojasJ.Las Mujeres de Cervantes. Barcelona: Montaner y Simón editores; 1916. Pages 101-12.

6. García Barreno PR. La Medicina en El Quijote y en su entorno. In: Sánchez Ron JM. La ciencia y El Quijote. Barcelona: Crítica; 2005.Pages 155-79.

7. Aramayo Zamora M. Todo ocurre en el par 21 (aspectos genotípicos). In: Aramayo Zamora M. La Persona con sindrome de Down. Caracas: Universidad Monteávila; 2016. Pages 57-72.

8. Ballesta-Martínez MJ, Guillén-Navarro E. Síndrome de Noonan. Protoc Diagn Ter Pediatr. 2010;1:56-63. [Accessed on: June $\left.20^{\text {th }}, 2019\right]$. Available at: http://www.aeped.es/sites/ default/files/documentos/sindrome_de_noonan.pdf.

9. Garvía Pañuelas B. Relaciones afectivas y sexualidad. Síndrome de Down. Barcelona: Fundació Catalana Síndrome de Down; 2011. [Accessed on: June 22 $2^{\text {nd }}, 2018$ ]. Available at: https://www.sindromedown.net/wp-content/ uploads/2014/09/87L_relaciones.pdf.

10. Tovar Mattar M. Estamos enamorados y nos queremos casar. In: Aramayo Zamora M. La Persona con síndrome de Down: hechos, mitos, problemas, sugerencias. Caracas: Melvin C.A.; 2016.Page 103.

11. Nabokov V. Engañoy Crueldad. In: Nabokov V. Curso sobre El Quijote. Barcelona: Ediciones B, S. A.; 2004.Page 112. 